\title{
PENGEMBANGAN PRODUK KEMASAN BERBAHAN DASAR KELOR DI DESA GANGGANGTINGAN KECAMATAN NGIMBANG KABUPATEN LAMONGAN
}

\author{
Ririn Febriyanti ${ }^{1)}$, Slamet Boediono') \\ 1)Program Studi Pendidikan Matematika, STKIP PGRI Jombang, Jawa Timur, Indonesia \\ Corresponding author: Ririn Febriyanti \\ E-mail : ririnfebriyanti28028201@gmail.com
}

Diterima 01 Juli 2021, Direvisi 20 Juli 2021, Disetujui 21 Juli 2021

\begin{abstract}
ABSTRAK
Daerah Lamongan terutama di kecamatan Ngimbang mayoritas kondisi alam nya hanya ada persawahan dan hutan. Apalagi di daerah Dsn. Tingan, Ds. Ganggangtingan yang terkenal karena terdapat banyak pohon kelor. Dengan alasan tersebut, Home industri "StiksQu" melihat peluang dengan memproduksi camilan yang terbuat dari campuran sayur yang menyehatkan (kelor). Tetapi Lama kelamaan bisnis stik sayur kelor ini memiliki tingkat persaingan yang tinggi dan ketat sehingga diperlukan inovasi dan pendampingan agar home industri ini tidak gulung tikar.. Adapun permasalahan yang dihadapi adalah (1) Sarana dan prasarana dalam bidang produksi kurang memadai, (2) belum diberikan kemasan yang baik pada produk stik yang dipasarkan dan (3) belum diberikan labelling untuk mengenalkan produknya. Metode yang digunakan dalam kegiatan pengabdian masyarakat ini dengan pendampingan dan praktik Prosedur rencana kegiatan dibagi 5 tahap yaitu tahap observasi, perencanaan (plan), pelaksanaan kegiatan (do), refleksi (see), dan penyusunan laporan. Setelah diadakan kegiatan pengabdian ini, home industri "StiksQu" dapat memproduksi stik yang berbahan dasar kelor dengan berbagai macam varian yaitu original, pedas, keju. Serta memiliki pengetahuan tentang cara pengembangan bisnis usaha yang baik meliputi segi produksi dengan cara memberikan gilingan pasta, pengemasan lebih bervariatif, serta pemasaran secara online (media sosial).
\end{abstract}

Kata kunci: peningkatan; olahan Kelor; produk kemasan.

\begin{abstract}
The Lamongan area, especially in the Ngimbang sub-district, the majority of its natural conditions are only rice fields and forests. Especially in the Dsn area. Tinan, Ds. Ganggangtingan is famous for its many Moringa trees. For this reason, the Home industry "StiksQu" sees an opportunity by producing snacks made from a healthy mixture of vegetables (moringa). But over time the moringa vegetable stick business has a high and tight level of competition so innovation and assistance are needed so that this home industry does not go out of business. The problems faced are (1) inadequate facilities and infrastructure in the production sector, (2) not yet given good packaging on the stick products that are marketed and (3) has not been given labeling to introduce the product. The method used in this community service activity is with assistance and practice. The activity plan procedure is divided into 5 stages, namely the observation stage, planning (plan), activity implementation (do), reflection (see), and report preparation. After this service activity was held, the home industry "StiksQu" was able to produce sticks made from moringa with various variants, namely original, spicy, cheese. And have knowledge about how to develop a good business business including in terms of production by providing pasta mills, more varied packaging, and online marketing (social media).
\end{abstract}

Keywords: improvement; moringa processed; packaged products.

\section{PENDAHULUAN}

Daerah Lamongan terutama di kecamatan Ngimbang mayoritas kondisi alam nya hanya ada persawahan dan hutan. Apalagi di daerah Dsn. Tingan, Ds. Ganggangtingan yang terkenal karena terdapat banyak pohon kelor. Menurut (Nurcahyatai, 2014) Kelor (Moringa oleifera) tumbuh dalam bentuk pohon, berumur panjang (parenial) dengan tinggi 7-12 m.
Masyarakat Indonesia mengenal daun kelor sebagai sayur yang dimasak menjadi sayur bening, mereka mengolah daun kelor hanya sebatas untuk sayur pendamping nasi, dan buanya yang bernama klentang juga digunakan hanya untuk menjadi sayur, selain itu daun kelor tidak termanfaatkan lagi. Adapun manfaat dari daun kelor sangat banyak dan bagus untuk kesehatan. Manfaat dari daun kelor (Hendarto, 
2019) adalah sebagai berikut yaitu berkhasiat mengatasi berbagai keluhan yang diakibatkan oleh kekurangan vitamin A (gangguan penglihatan), kekurangan choline (penumpukan lemak pada lever), kekurangan vitamin B1 (beri-beri), kekurangan vitamin B2 (kulit kering dan pecah-pecah), kekurangan vitamin B3 (dermatitis), kekurangan vitamin C (Pendarahan gusi), kekurangan kalsium (osteoporosis), kekurangan zat besi (anemia), serta kekurangan protein (rambut rontok dan gangguan pertumbuhan anak). Daun kelor juga berkhasiat sebagai obat sesak nafas dan encok (Hendarto, 2019). Saat memulai bisnis stik sayur ini, mitra menjalankan dengan modal kecil. Dimana stik ini dijual ataupun diproduksi pada lingkup rumahan (Home Industry) dengan skala kecil,tetapi lama kelamaan muncul persaingan diantaranya muncul camilan berupa mie lidi, seblak yang digemari remaja milenial. Dengan adanya persaingan tersebut, maka tim pengabdi memberikan perhatian untuk meningkatkan penjualan dari mitra Home Industry "StikQu" yaitu dalam hal variasi produk dengan cara harus membuat stik dengan varian rasa, serta labelling, membantu dalam hal pemasaran.

\section{METODE}

Metode yang digunakan dalam kegiatan pengabdian masyarakat ini dengan pendampingan dan praktik. Lokasi bertempat Desa Ganggangtingan Kecamatan Ngimbang Kabupaten lamongan. Pemilik Home Industri ini bernama Ayu Triska. Home Industri ini mengelola stik daun kelor ini selama kurang lebih 3 tahun. Adapun prosedur rencana kegiatan yang akan diberikan sebagai berikut:

1. Tahap observasi, pada tahap ini tim berjumlah 2 orang melakukan observasi atau survey di Desa Ganggangtingan Kecamatan Ngimbang Kabupaten Lamongan yang menjadi mitra program pengabdian bagi masyarakat.

2. Tahap perencanaan (Plan), pada tahap ini tim melakukan perencanaan kegiatan pelatihan dengan mempersiapkan materi yang akan disampaikan, peralatan yang dibutuhkan sebelum dan saat pelaksanaan kegiatan, serta koordinasi dengan tim pengabdi untuk tahap pelaksanaan kegiatan.

3. Tahap pelaksanaan (do), kegiatan pada tahap ini adalah memberikan pendampingan, diskusi pendampingan kemasan dan labelling serta pembuatan kemasan dan labelling.

4. Tahap refleksi (see), tahap ini adalah dengan rincian sebagai berikut: memberikan evaluasi/refleksi kepada mitra. Hal ini dilakukan untuk mengetahui sejauh mana mitra ini bisa melaksanakan hasil pendampingan dan mengenalkan produk secara luas kepada konsumen baik dalam bidang administrasi dan pemasaran serta produk yang dihasilkan..

5. Penyusunan Laporan akhir ini dilaksanakan pada tahap akhir kegiatan untuk lebih detail dalam proses penyusunan kegiatan pengabdian masyarakat dengan mitra "StiksQu".

\section{HASIL DAN PEMBAHASAN}

Hasil dari kegiatan pengabdian ini diantaranya:

1. Pada tahap pelaksanan, tim pengabdi yang berjumlah 2 orang dengan dibantu satu mahasiswa STKIP PGRI Jombang memberikan pengetahuan dan penjelasan kepada home industry "STIKSQU" selaku mitra dalam pengabdian ini bagaimana cara meningkatkan manajemen wirausaha melalui usaha yang telah ditekuni selama ini. Adapun kegiatan yang diberikan yaitu:

a. Untuk kecepatan dalam produksi yang awalnya mitra hanya menggunakan rolling pin, pengabdi membantu memberikan sebuah gilingan pasta untuk mempermudah dalam memproduksi stiksqu dalam jumlah banyak.

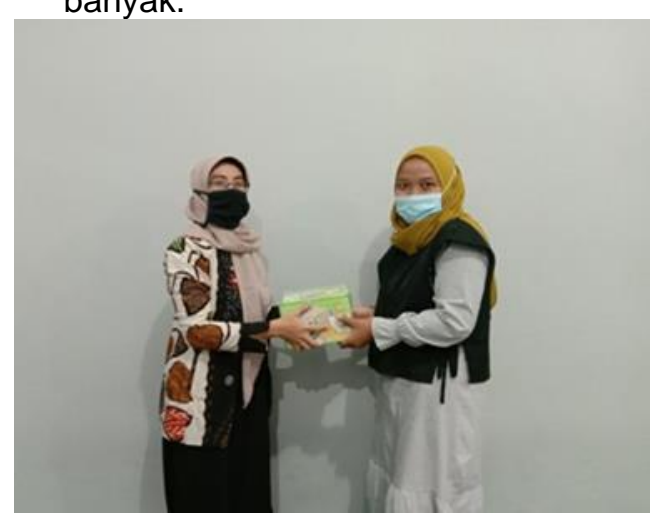

Gambar 1. Penyerahan gilingan pasta

b. Pemasaran membantu mitra kami dalam memasarkan atau mengenalkan produk untuk masyarakat luas. Sehingga tingkat penjualan dari produk akan menghasilkan tingkat pejualan yang tinggi. Jika pada awalnya penjulan produk hanya disekitar lingkungan mitra maka dengan bantuan aplikasi media sosial seperti WhatsApp, Facebook, Instagram, dan Youtube, memberikan kemudahan bagi mitra dalam memasarkan produknya. Selain itu kami juga membuatkan banner kecil dengan ukuran 1,75 x 1 meter kepada mitra untuk di letakkan 
didepan rumah. Banner ini bertujuan untuk mempermudah pelanggan mencari lokasi sehingga bisa membantu mempromosikan produk yang dijual. Serta mempromosikan lewat media sosial yang telah dilakukan. Dengan pemasaran ini diharapkan dapat meningkatkan kuantitas pembeli.

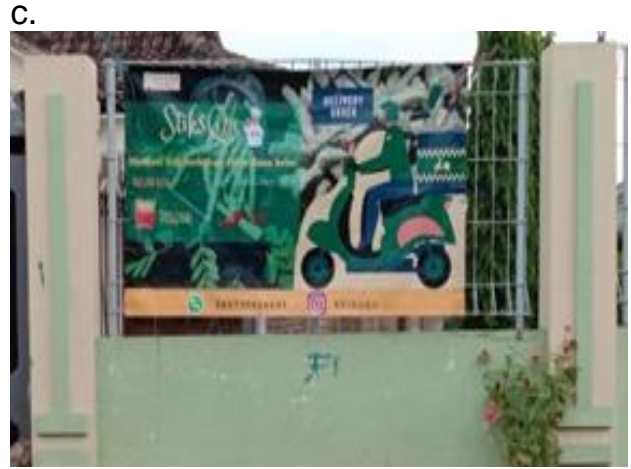

Gambar 2. Banner sebagai salah satu bentuk promosi

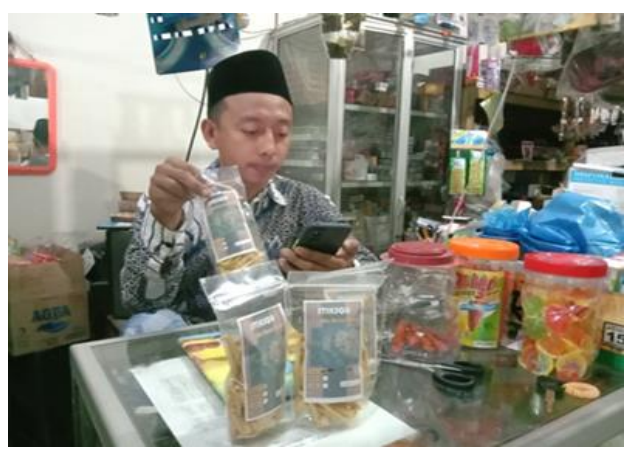

Gambar 3. Pemasaran Stiksqu dalam bentuk offline

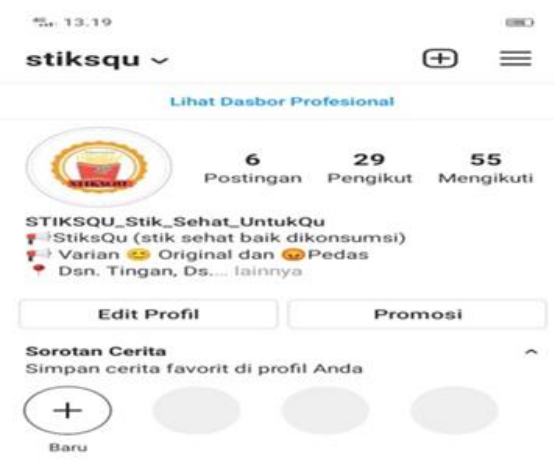

用

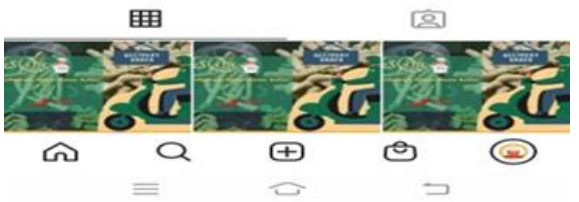

Gambar 4. Pemasaran Stiksqu dalam bentuk online

d. Pemilik Home industri "STIKSQU" dapat memproduksi berbagai stik berbahan dasar kelor dengan berbagai macam varian rasa. Pengabdi membekali pemilik usaha stiksqu dengan berbagai varian rasa agar lebih menarik minat pembeli untuk menikmati stiksqu, seperti rasa pedas pada stiksqu dibuat dari campuran bon cabe level original dan ditaburi oleh balado pedas yang menambah sensasi pedas dan gurih pada stik yang menambah minat pencinta stik. Penambahan variasi pada stik dikarenakan pelanggan sekarang banyak yang menyukai rasa pedas terutama pelanggan yang masih duduk di bangku sekolah.

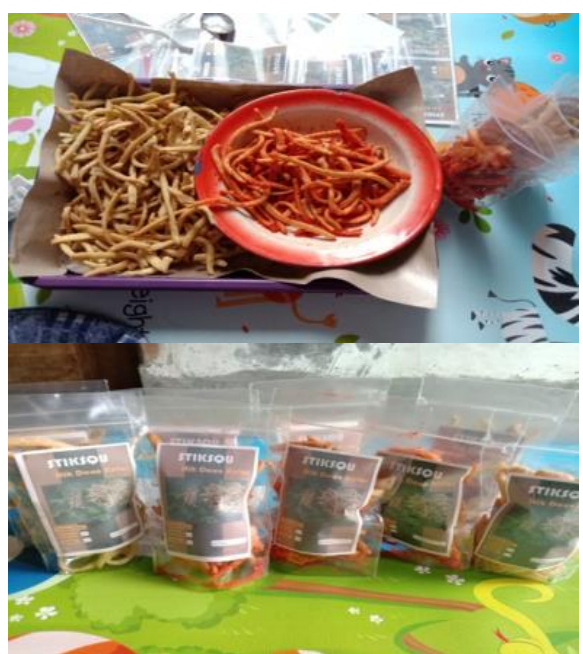

Gambar 5. Varian Produk Stiksqu

e. Membekali pemilik home industri dalam hal pengemasan dan labelling yang menarik sehingga dapat mengenalkan produknya kepada masyarakat luas serta dapat menjadikan produk khas daerah tersebut, Pengabdi membantu dalam pembuatan kemasan yang menarik yakni dengan memberikan plastik standing pouch yang sedang trend seperti saat ini, Sebelumnya mitra hanya menggunakan plastik biasa untuk kemasan stik. Tim Pengabdi juga membantu membuat design labelling pada produk yang dipasarkan oleh mitra. Dalam proses pembuatan labeling sebenarnya mitra sudah ada, namun dari segi desain kurang menarik, untuk itu tim pengabdi membantu membuatkan design kepada mitra. 


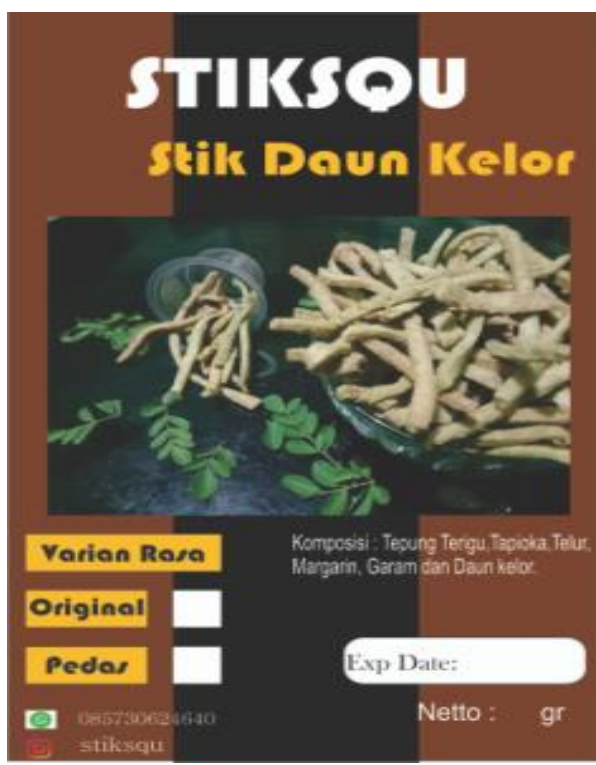

Gambar 6. Label Produk Stiksqu

Tabel 1. Prosentase Pencapaian Kegiatan Pengabdian

\begin{tabular}{|c|c|c|}
\hline No & $\begin{array}{c}\text { Kegiatan } \\
\text { Pengabdian }\end{array}$ & Prosentase \\
\hline 1 & \begin{tabular}{l}
\multicolumn{2}{c}{ Membantu } \\
dalam hal \\
produksi stik \\
sayur dengan \\
memberikan \\
bantuan gilingan \\
pasta sehingga \\
dapat \\
memperlancar \\
dalam proses \\
produksinya.
\end{tabular} & $100 \%$ \\
\hline 2 & \begin{tabular}{l}
\multicolumn{1}{c}{ Membantu } \\
dalam \\
pembuatan label \\
pada kemasan \\
sehingga terlihat \\
lebih menarik
\end{tabular} & $100 \%$ \\
\hline 3 & \begin{tabular}{l}
\multicolumn{2}{c}{ Membantu } \\
dalam hal \\
pemasaran \\
dengan \\
memasang \\
banner, serta \\
mempromosikan \\
lewat media \\
sosial
\end{tabular} & $100 \%$ \\
\hline
\end{tabular}

Pada tahapan kegiatan pengabdian selanjutnya adalah evaluasi hasil pendampingan manajemen,pembuatan label dan pemasaran. Mitra :

Evaluasi/ Refleksi Yang Dilakukan Kepada

1. Pembuatan Produksi StiksQu sebelum adanya kegiatan pengabdian ini, mitra masih mengalami kesulitan karena alat produksi masih kurang memadai. Sehingga langkah awal yang dilakukan tim pengabdi yaitu memberikan sebuah gilingan pasta dengan tujuan agar bisa meningkatkan hasil produksi stik sayur yang berbahan dasar daun kelor.

2. Pembuatan label yang awalnya dikemas di diplastik satu kilograman, diperbarui dengan menggunakan plastik standing pouch sehingga lebih praktis karena ada klip penutup nya. Label adalah identitas suatu produk. Tanpa label kita tidak dapat membedakan antara produk satu dengan yang lainnya. Label merupakan bagian yang sangat penting dari suatu produk agar konsumen dapat memperoleh produk sesuai yang diharapkan dan sehat serta aman dikonsumsi. Label harus memberikan informasi yang jelas, detail dan mudah dimengerti oleh masyarakat umum.

3. Promosi dan manajemen Usaha. Untuk saat ini ada banyak sekali alat promosi bisnis yang bisa menjadi pilihan, salah satunya yaitu dengan menggunakan banner. Dimana banner ini dapat diletakan di area terbuka ataupun tertutup. Dengan seiring berkembangnya dunia teknologi maka banner menjadi salah satu alat promosi yang dicetak dengan menggunakan teknik digital printing sehingga nantinya desain banner dan juga informasi yang ada didalam banner bisa dapat terlihat dengan jelas serta menarik. Promosi offline dengan menggunakan banner seperti ini masih menjadi andalan untuk mendongkrak penjualan secara cepat. Setelah ada kegiatan pengabdian ini maka membantu melakukan promosi dengan memasang banner kecil di depan rumah Mitra ( home industri "STIKSQU"). Sesuai dengan tujuan promosi melalui banner tersebut maka produk mitra dapat lebih dikenal luas oleh konsumen selain menggunakan media sosial

\section{SIMPULAN DAN SARAN}

Kegiatan penelitian yang telah dilaksanakan oleh tim pengabdian pada bidang manajemen usaha yang meliputi promosi dan labeling pada produk berbasis olahan dari daun kelor. Tim pengabdi dalam kegiatan ini mengatasi masalah tentang produksi yaitu dengan memberikan satu unit gilingan pasta atau mie yang berguna untuk memperlancar dalam proses produksi stik. Di samping itu dalam pembuatan kemasan atau labeling, tim pengabdi berdiskusi dengan mitra guna membuat label kemasan yang bagus dan menarik sehingga dapat menarik minat para 
konsumen untuk membeli, serta pembuatan banner yang berfungsi untuk promosi.

Adapun saran dari pelaksanaan Kegiatan Pengabdian ini diantaranya: 1).Tim pengabdi berharap agar mitra dapat berkreasi lagi dalam menciptakan inovasi stik berbahan dasar kelor selain varian rasa misal dengan bentuk yang berbeda yaitu bubur bayi yang berbahan dasar kelor, atau mie yang berbahan dasar kelor; 2). Setelah dibuatkan kemasan, selanjutnya mitra seyogyanya mendaftarkan untuk PIRT produknya sehingga bisa lebih terjamin dan aman dikonsumsi.

\section{UCAPAN TERIMAKASIH}

Terimakasih kepada Pimpinan STKIP PGRI Jombang dan Tim P3M STKIP PGRI Jombang yang telah memberikan kesempatan kepada kami untuk melakukan kegiatan pengabdian kepada masyarakat, dan kepada mitra home industry "Stiksqu" bertempat di Desa Gagangtingan Kabupaten Lamongan yang berkenan untuk bekerjasama dengan tim pengabdi.

\section{DAFTAR RUJUKAN}

Hardinsyah dan Supariasa, I Dewa Nyoman (2016). IImu Gizi Teori Dan Aplikasi. Jakarta: Kedokteran EGC.

Hendarto, Dani. (2019). Khasiat Jitu Daun Kelor Dan Sirih Merah Tumpas Penyakit. Yogyakarta: Laksana.

Kotler dan Keller. (2009). Manajemen Pemasaran. Jilid I. Edisi ke 13. Jakarta: Erlangga.

Krisnadi, Dudi. (2015). Kelor Super Nutrisi. Blora: Moringa Indonesia.

Nugrahani, Rahina. (2015). Peran Desain Grafis pada Label dan Kemasan Produk UMKM. Fakultas Bahasa dan Seni Universitas Negeri Semarang.https://journal.unnes.ac.id/n ju/index.php/imajinasi/article/view/8846 15795.

Nurcahyati, Erna. (2014). Khasiat Dahsyat Daun Kelor. Jakarta: Jendela Sehat.

Oentoro, Deliyanti. (2010). Manajemen Pemasaran Modern. Yogyakarta:: Laksbang Pressindo.

Rahayu, Darsiti. (2016). Penambahan Tepung Daun Kelor Dalam Pembuatan Mie Sebagai Sumber Gizi Dengan Penambahan Ekstrak Umbi Wortel Sebagai Pengawet Alami.Surakarta: Universitas Muhammadiyah Surakarta. https://eprints.ums.ac.id 